\section{Gender inequality: determinants and outcomes in Nigeria}

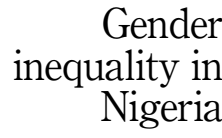

\section{Department of Economics, Federal University of Agriculture, Abeokuta, Nigeria}

\begin{abstract}
Purpose - This paper aims to shed light on gender inequality in Nigeria exploring new available data. It makes a case for attention to women empowerment and likely economic outcomes. The general objective of the research work is to ascertain the direction of gender inequality and show the pattern of inequality. Also, sectoral trends are obtained by analyzing and examining income inequality in Nigeria.

Design/methodology/approach - The paper obtained data from the Living Standard Measurement Survey Wave 3, published 2017 with emphasis on the earnings that accrued to both male and female. The study employed the ordinary least square (OLS) method to show the relationship between the mean income and other parameters such as the sector of employment, marital status and education level. Theil's entropy index was used to measure the within and between inequality that exist in the economy and across regions and sectors while adopting the overcrowding theory.

Findings - The result shows that gender inequality is more pronounced across the region, location and in some sectors of employment than the others. Geographical area has a higher effect on earnings disparity but is more pronounced among females. Also, the result showed that gender within inequality was high in the regions, education, location, and marital status while a higher level of education contributes to high wages for women. However, married women are more deprived.

Originality/value - This study has further revealed the need to bridge the gap gender inequality has caused in Nigeria, especially related to income, education and geographical location, with a focus on both opportunities and outcomes.
\end{abstract}

Keywords Earnings, Gender, Inequality, Outcome, Women

Paper type Research paper

\section{Introduction}

The 5th goal of the sustainable development goal (SDG) is focused on gender equality. Global attention is on achieving gender equality and empowering all women and girls. Aside from agriculture, women in paid employment account for $41 \%$ against $35 \%$ as of 1990 . The 5 th SDG aim to empower all women and girls to ensure gender equity and ultimately end all acts of discrimination against the female gender.

The argument for or against gender inequality is a conversation that has remained in the corridor of global debate. In the past, some literature was of the opinion that gender inequality might actually lead to an increase in economic growth (Mayoux, 1995; Klasen, 2002; Dorius

\section{JEL Classification — D31, D63, E24, J16.}

(C) Oluyemi Theophilus Adeosun and Kayode Ebenezer Owolabi. Published in Journal of Business and Socio-economic Development. Published by Emerald Publishing Limited. This article is published under the Creative Commons Attribution (CC BY 4.0) licence. Anyone may reproduce, distribute, translate and create derivative works of this article (for both commercial and non-commercial purposes), subject to full attribution to the original publication and authors. The full terms of this licence may be seen at http://creativecommons.org/licences/by/4.0/legalcode

The authors acknowledge everyone who have contributed to the great success of this research work. The authors appreciate Professor Biola Phillip for her assistance towards this research paper. Special thanks to Dr. Omolara Faboya for her support too.

Funding details: The authors received no direct funding for this research work.

Declaration of interest statement: The authors declare no conflict of interest.
Received 30 January 2021 Revised 24 March 2021 Accepted 5 June 2021

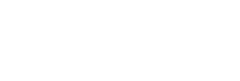


JBSED

1,2

and Firebaugh, 2010; Kleven and Landais, 2017; Worsdale and Wright, 2020). However, other authors (Essien et al., 2016; Kleven and Landais, 2017; Falk and Hermle, 2018) have revealed that gender inequality negatively impacts the economy. Gender inequality is a problematic issue as it lowers wellbeing and is regarded as a form of injustice in the very conception of equity (Klasen, 2008; UNDP, 2015; Rewhorn, 2020).

Historically in Nigeria, certain tribes treated men preferentially for economic empowerment and inheritances (Olanrewaju et al., 2015; Pathak, 2017). For instance, the Igbos do not include women or girls in a will when sharing land or another asset (Agbasiere, 2015; Azuakor, 2017). Women are thought to be fit for the kitchen and assist with farm duties. This makes them dependents and subservient to their male counterpart (Ene-Obong et al., 2017). Gender inequality is a multifaceted concept that incorporates both opportunities and outcomes. The latest review of the Nigerian economy by the International Monetary Fund (IMF) revealed that closing the gender gap is key to achieving higher growth in the economy, enhancing productivity and greater economic stability (Archibong, 2018; Adegbite and Machethe, 2020).

There has been a lot of advocacy by both the government and civil societies making a case for training the girl child and providing equal opportunities over the years (Abendroth et al., 2017; Connell et al., 2020). Over time, with the advent of western education, exposure and enlightenment, there is a need to see how the gap caused by inequality and discrimination against women has been bridged and to what degree. In Nigeria, women dominate the unpaid job sector, twice the figure for men. The economic value of females was projected to be about $30 \%$ of the gross national product (UNDP, 2015). Like other parts of the world, women in Nigeria face several discriminations that limit their full capacity.

Gender refers to the roles, behaviors, activities, attributes and opportunities that any society considers appropriate for girls and boys, and women and men. Gender interacts with, but is different from, the binary categories of biological sex (World Health Organization, 2020). Gender can also be the state of being male or female. Inequality, on the other hand, can be defined as a state of being unequal or unfair. Gender inequality is seen as the disparity between the male and female gender. The concept of inequality is broad; it is expressed over the entire population and captures those below a certain poverty line (World Bank, 2011; UNDP, 2013). Inequality is associated with segregation, economically or socially. The presence of barriers mostly drives inequality. These barriers hinder upward movement in social classes through income and wealth crystallization. These barriers give certain highclass people access to a better stake of societal resources, hence make them better off than those in the lower class (Anyalebechi, 2016; Kleven and Landais, 2017; Matthew et al., 2020).

Several factors account for the gap in gender-based earning, such as segregation by occupation and industry, differences in physical structure, education and skill acquisition, contributing to differences in earning (Akinbi and Akinbi, 2015; Para-Mallam, 2017). However, the recent discovery shows that some of this gap is being closed gradually, such as the gap regarding educational attainment and horizontal occupational segregation is further reduced. These events have contributed to the reduction of gender gaps in wages and earnings. (Klasen and Santos-Silva, 2018)

The economy of Nigeria is a mixed economy with emerging markets and is of middleincome. With key sectors such as manufacturing, communications, technology, financial services, entertainment on the increase each year, it is ranked as the 27th largest economy globally considering nominal gross domestic product (GDP) and the 23rd largest when considering purchasing power parity (IMF, 2020). It is the largest economy in Africa, with its growing manufacturing sector becoming the biggest in Africa in 2013 (Fantom and Serajuddin, 2016; Lawal et al., 2018). Among West African countries, Nigeria is the largest producer of goods and services. (Manufacturing sector report 2015; Isiksal and Chimezie 2016; Ovadia and Wolf, 2018). Nigeria's debt to GDP ratio has been on the increase though 
well below many developing nations like her. In 2008, the debt to GDP ratio was $7.2 \%$; however, as of 2019, the figure stood at 16.2\% (Onafowora and Owoye, 2019; CEIC, 2019).

Nigeria is the most populous nation in Africa, with an estimated population of about 200 million. As of 2019, the Nigeria Bureau Statistics estimated that about 40\% of Nigerian population live below the poverty line. Furthermore, Nigeria's outlook in the Human Capital Development Index (0.539) as of 2019 is nothing to be proud of, ranking 158 among nations of the world (UNDP, 2019). Going by the above knowledge, a nation as populous as Nigeria cannot take with levity the problem of gender inequality if she wants her economy to grow. Therefore the problem of gender inequality must be reduced to the minimum that she can attain.

Over the years, research works have shown clearly that there is an imbalance in gender allocation in society and sectors of the economy at large (Ndubuisi, 2017). Inspite of several strategies put in place by the United Nations, the government of nations, and various private institutions to reduce gender inequality to the bare minimum, gender inequality continues to be a menace to society. In light of this imbalance across gender, this study seeks to critically evaluate its impact on income across gender in Nigeria, emphasizing the critical sector of the Nigerian economy and the geographical distribution of Nigeria. This study raises a major concern and the need to carefully outline the determinants of gender inequality in the country and practically see if there has been improvement upon comparison with previous studies as the research work looks at new data sets to show the current state of gender inequality in income in the Nigerian economy.

This research work is divided into five sections. Section two provides a literature review on the topic, that is, previous works on or related to the topic. Section three provides the methodological outlook of the study, while section four presents the result and discusses the findings. Section five provides the conclusion and recommendations.

\section{Theoretical review}

\subsection{Empirical review}

The study by Fatukasi and Ayeomoni (2015) exposes the consequences of income inequality on health indicators in Nigeria. Considering data from the IMF between 1980 and 2014, the study employs a dynamic ordinary least square (OLS) methodological approach. Evidence supports that income inequality significantly affects health indicators in Nigeria for the period under review. Consequentially, per capita income, saving level and educational attainment contribute positively to health indicators in the county.

Osunde (2015), using data from ILO, studied the labor market for male and female workers. It was found that the labor market demand for both genders differs, favoring the male. Osunde (2015) put the adult male's market participation rate in the country to be $73.7 \%$ as of 2000 . This figure declined to $71.7 \%$ in 2005 and $70.6 \%$ in 2007 ; consequently, female labor participation during this period stood at $38.7 \%$ in 2007 , a rise from $38.1 \%$ in 2005 and $37 \%$ in 2000 . However, evidence suggests that women in the age bracket of $50-55$ have a high labor market participation rate. This means that many women are active in the labor market only after the childbearing period.

The study confirmed income inequality, which is more pronounced in the wage-paying job than the self-employment job. The source of income is attributable to the level of disparity in earning. However, based on Theil index measurement, urban inequality is lower than rural; urban is 0.334 and rural is 0.672 in Nigeria.

In Nigeria, girl child education is threatened just like other countries of the world. Girl child education is needed for poverty reduction, ensuring societal tolerance and economic development. Akinbi and Akinbi (2015) examine the root gender disparity in education in Nigeria; factors such as cultural beliefs and practice, family financial constraints, religious 
JBSED

1,2

168

encumbrances, and environment are highlighted as a cause of disparity in education in Nigeria between the male child and the girl child. The study further highlights the implication of such disparity in a nation, citing women's high dependency on men, crises and its effect on infant mortality. The study poses that universal education should be a top priority for the government, ensuring free and compulsory education at the secondary school level. Furthermore, the northern part of the country needs more enlightenment on education value.

Women participation in politics in Nigeria is on the low; women are heavily discriminated against and given little or no opportunity to participate in politics Anyalebechi (2016) identified factors that contribute to the high inequality gap in women participation in politics, factors such as culture and norms favoring the male; education level of women also contribute to the low participation; many women are not educated and relegated to doing household chores. The political factor and the rule of law is not favorable to women in politics.

Mandel's (2016) findings indicated that characteristics that increase gender inequality in pay occupation through exclusionary practices really work the opposite direction on within occupation gender inequality. Furthermore, occupation is a strong system that cannot be overridden by an individual characteristic. This shows the superiority of the effect of occupation over the character of an individual. Besides, democratic occupation is found to close the gender pay gap more than a less democratic occupation. The study shows that democratic occupation reduces the gender pay gap between $45 \%$ and $63 \%$. In the US, the gender wage report 2017 highlights that women's ratio to men's median annual earnings is $80.5 \%$ in 2017. This figure was recorded for the year 2016, which means that the gender wage gap is of $19.5 \%$. The report shows that gender parity in earning will be achieved at such a growth rate in 2059. Furthermore, comparing the white and black average monthly earning, the black average monthly income was at a disadvantage, earning just about $60 \%$ of the white average monthly income (Hegewisch and Williams-Baron, 2018).

Checchi and van De Werfhorst studied the relationship between education dispersion and earnings (2018). In their study, there exists a positive relationship between educational attainment and the level of earning. Differences in skills acquired also add to the inequality gap as those who possess better skills and education earn more. The study was in line with the neoclassical economic theory. In another study by Busemeyer (2015), inequality in skill was examined against the parental background of some set of 15-year-old students using data from OECD. The result shows no relationship between the student's parental background, education opportunity and skills acquired.

The socioeconomic impact of inequality was examined in Israel by Kaplan and Herbst (2015), emphasizing the contribution of relative income, household income and education inequality to divorce in Israel. The result shows that couples in the lower end of the socioeconomic class tend to divorce more in Israel. Furthermore, a higher level of education of both couples reduces the risk of divorce. This shows that equity in education can help curb the menace of divorce. In another vein, a wife earning higher than her husband increases the risk of divorce in Israel. This shows that inequality in earning favoring the female can result in divorce.

The participation of women in the e-wallet program and the use of modern agricultural tools was the focus of Uduji and Okolo-Obasi (2018). The study examines the impact of the government e-wallet on young females' performance in the rural agriculture sphere in contributing to the enhancement of female productivity in the agriculture sector. Evidences suggest that the program has helped young females access infrastructure and helped close the inequality gap on their male counterparts. Furthermore, women engaged more in the farm value chain than they did previously, earning more and closing female-male earnings inequality in Nigeria's rural agriculture sector.

Clark (2011), in his paper "World health inequality: Convergence, divergence, and development," looked at inequality in health using infant mortality rate and life expectancy 
and checked for the convergence and divergence in the variables and noted that there is a convergence in life expectancy for the years under study; interestingly, there is a rapid divergence in the infant mortality rate. It was confirmed that in emerging countries, economic development has more bearing on life expectancy than it has on the infant mortality rate. However, this case does not hold in advanced economies. This shows that a positive effect of GDP per capita on life expectancy attenuates at higher development levels. In contrast, the negative effect of GDP per capita on infant mortality grows stronger.

Akinbi and Akinbi (2015) examine inequity in healthcare utilization through an analysis of the Nigeria situation for the period of 2010; using the Nigerian living standard survey (NLSS) data, they adopted the horizontal inequity (HI) index to make their findings. Their result shows that inequity in health-care utilization in the country is generally skewed against the poor as the analysis established evidence about the poor with similar medical needs as the rich have access to less health-care service. Also, health-care services' utilization rate is found to be positively related to household expenditure, while age and health status are significant factors determining health-care visits.

Fidelis et al. (2006) studied labor force participation, earnings and inequality in Nigeria using the General Household Survey (GHS) 1999 for Nigeria. The study makes use of the Gini coefficient, Theil's entropy index, ordinary least squares technique, and other techniques in its analysis and finds that inequality is more pronounced in paid employment than in the selfemployed segment of the Nigerian labor force and inequality is generally higher in the rural areas than in the urban areas and within subgroups.

\subsection{Overcrowding theory}

The overcrowding theory, a work of Amasa Walker of Oberlin in 1866, explains that "low wages of women, even where physical differences do not matter, is because of their exclusion from many employments, which force women to crowd into the remaining occupations, forcing down wages." Walker discovered that the average monthly income of male teachers, $\$ 49.87$, was greater than that of the female teachers, $\$ 19.63$ in Massachusetts's public schools in $1857-1858$.

Over the years, gender disparity has been attributed to males' physical structure, making them more productive and deserving of more earnings than females. However, Walker believed that even in jobs that do not require physical strength or physical differences are not considered, males still dominate, leaving females to be excluded from many job opportunities. This forces female labor to other available occupation, given their large number, the wage is forced down. He looked to widen the range of occupations open to women with more equal wages. Of course, arguments about pay disparities, differences in education by gender, the relationship between family responsibilities and wages and crowding of women into particular occupations have been staples of studying the economic status of women ever since. We leverage on this theory as we seek to examine the role the employment sector plays in earning capacity along gender in Nigeria.

\subsection{Neoclassical economics theory}

Neoclassical economics is defined by its reliance on rational choice theory and was largely established as homogeneous. It is a theory that focuses on determining goods, output and income distribution through the forces of demand and supply in the market. Hypothesizing maximization of utility by income constrained individuals and profit by firms facing production cost and managing production factors. After the Second World War, white male economists were greatly influenced by Victorian ideology. This physical embodiment induced patriarchy's reproduction over the years (Ferguson, 1969; Aspromourgos, 1986). This patriarchal, discriminatory root of neoclassical economics has led to the fallible analysis 
JBSED 1,2 of women's role in society. This continued the notion that men are breadwinners and women are caregivers, which led the economists to view household labor as women's work. The domestic roles played by women, including social reproduction, has long been categorized as unproductive. Hence, no economic value is attached since the activities are not captured in the market sphere.

\section{Research methodology}

3.1 Sources of data

The scope of this research work will cover the period of 2015-2016 using the Living Standard Measurement Survey (LSMS) Wave 3 for Nigeria. The GHS panel is a nationally representative survey of 5,000 households, representing the geopolitical zones (at both the urban and rural levels). The households included in the GHS- panel are a subsample of the overall GHS sample households. The report presents findings from the third wave of the GHS panel, which was implemented in 2015-2016. The data for the research work are a collaborative work of the National Bureau of Statistics (NBS), the Federal Ministry of Agriculture and Rural Development (FMA and RD), the Bill and Melinda Gates Foundation (BMGF) and the World Bank (WB).

\subsection{Analytical procedure}

This research work utilized individuals in paid employment who are between 15 and 65 years of age. To understand the data, we explored the data using descriptive statistics (Young and Wessnitzer, 2016). We described the distribution of the sample between male and female who are in paid employment along gender, across age group (15-65), location (rural or urban), region (Northeast, North West, North Central, South East, South West and South-South), and some selected sectors of employment (agriculture, industry and services) using the OLS technique (Kilmer and Rodríguez, 2017).

\subsection{Model specification}

The entropy index is a measure of "evenness" that is the extent to which groups are evenly distributed among organizational units (Massey and Denton, 1988). More specifically, Theil described entropy index as a measure of the average difference between a unit's group proportions and that of the system as a whole (Theil, 1972). The Theil index is the only multigroup index that can be decomposed into a sum of between- and within-group components (Reardon and Firebaugh, 2002) where $T=T_{w}+T_{b}$, which is the sum of the within-group inequality index.

Generally, Theil's $T$ is stated as

$$
G E(1)=\frac{1}{N} \sum_{i=1}^{N} \frac{y i}{y} \ln \left(\frac{y i}{\bar{y}}\right)
$$

While Theil's $L$ is defined as

$$
G E(0)=\frac{1}{N} \sum_{i=1}^{N} \ln \left(\frac{y i}{\bar{y}}\right)
$$

Where,

$y=$ total number of employed individuals in the sample

$\bar{y}=$ mean of employed individuals 
$y_{j}=$ total number employed in a subgroup (for example, region - North, West) with $N$ members

$\overline{y_{j}}=$ is the mean of employed individuals of this subgroup

Gender inequality in Nigeria

This decomposed inequality enables the assessment of the major contributions to inequality by different subgroups of the population according to gender, age groups, location, region and the sector of employment.

The within-group and between-group inequality was obtained from the equation, which enabled a comparison within and between the subgroups.

Using $L$ to represent GE (0),

$$
\begin{aligned}
& L=\sum_{i=1}^{n} \frac{1}{N} \ln \left(\frac{\bar{y}}{y_{i}}\right) \\
& =\sum_{j}\left(\frac{N_{j}}{N}\right) L_{j}+\sum_{j} \frac{N_{j}}{n_{j}} \operatorname{In}\left(\frac{\bar{y}}{y_{j}}\right)
\end{aligned}
$$

$n_{j}=\frac{N_{j}}{N}$, the proportion of those in the sample who are in the $j$ th subgroup.

Given the two time periods, we add the time subscripts;

hence,

$$
\Delta L=\sum_{j} n_{j}\left[\operatorname{In}\left(\frac{\bar{y}_{, 2}}{y_{, 1}}\right)-\operatorname{In}\left(\frac{\bar{y}_{j, 2}}{y_{j, 1}}\right)\right]+\sum j\left[L_{j}+\operatorname{In}\left(\frac{\bar{y}}{\bar{y}_{j}}\right)\right] \Delta n j+\sum_{j} n_{j} \Delta L_{j}
$$

The effect of changes in the relative mean number of employment and inequality is captured by the first term on the right (for example, a rapid change in the income of a small, rich group will likely result in greater inequality). The second term measures the effect of shifts in population from one group to another, while the third captures the size of changes in withingroup inequality. (Iceland, 2004). With this, the study was able to capture changes in relative mean incomes because of inequality. It enabled the measurement of the effect of changes in population from one group to another and capturing the changes in the within-group inequalities over time (Cowell, 2006).

In addition to the Theil index, we consider the OLS to examine the contribution of gender, location, region, educational level, marital status and the sector of employment on the log of monthly earnings. We hypothesis that all the variables have a positive relationship with the log of monthly earnings; where it was not so, we accepted the alternative.

\section{Results and discussion}

\subsection{Descriptive statistics}

Descriptive statistics show us the qualities of the data used, which allow us to proceed with the appropriate methodology for estimation.

According to gender, the data show that $49.03 \%$ are male, while $50.97 \%$ of the population are female. Furthermore, the majority of the sample comes from the rural area, with $71.10 \%$ from the rural region and $28.90 \%$ of the sample come from the urban region, with the total population of the individual understudy being 32,827. To further appreciate the data set and the need to evaluate the dimension of gender inequality along regions in the country, the data were broken down to the regions in the country along the gender line. Along the male distribution, the North East holds a higher population with $24 \%$, followed by North East with $18 \%$ followed closely by North Central with $17 \%$. Considering female distribution, North East holds a higher population with $22 \%$, while North East with $17 \%$ and North Central $17 \%$ are tied. 
JBSED

1,2

172

Table 1.

$T$-statistics of gender according to the sector of employment
The standard deviation values showed the extent to which the observations are dispersed around their respective means in Table 1 . The standard deviation to mean ratio of females is 3.87 and 4.38 for male, which are greater than 0.5, thus suggesting a high coefficient of variation (i.e. high dispersion). Also, considering the skewness statistics whose threshold value for symmetry (or normal distribution) is zero, none of the variables is exactly zero. However, for females, it is closer to zero (0.14) than the male (0.76). They are positively skewed since their skewness statistics are greater than zero. On the other hand, the kurtosis value, whose threshold is 3 , indicates that all variables are platykurtic (lowly peaked) with the values of 2.098 and 1.734 for males and females, respectively. This tends to prove the normality of the data.

Table 2 is a representation of the sectors in which the females in the sample are employed. About $44 \%$ of the females are engaged in buying and selling, 39\% in agriculture, while only about $6 \%$ work in the manufacturing sector of the economy; the sector of employment is key to earning; females dominate jobs that are semi-skilled, hence have low income; this further widens the inequality gap between them and the male folk.

Table 3 is the breakdown of the sectors of employment for males. Agriculture also constitutes the main employment sector for the male, with about $54.82 \%$ engaged in agriculture. This is in line with the general belief that the agriculture sector employs most of Nigeria's labor. Following in distance is buying and selling, which is $14.76 \%$; public administration $(5.42 \%)$ and personal services $(4.82 \%)$ are also common among males.

\subsection{Ordinary least square regression, Theil's entropy and the kernel density}

This section provides the estimated result from the models, such as OLS regression, Theil's entropy and the kernel density. It provides information on the population that earns a wage and those who do not earn a wage. It further explains the within- and between-gender inequality in income along with several characteristics.

Table 4 describes those who earn a wage in the economy and those who do not; by "has wage" we mean those who are in a formal working environment, while "no wage" refers to those who earn from the informal sector. As presented in the table, $48.48 \%$ of males have "no

\begin{tabular}{|c|c|c|c|c|c|c|c|}
\hline & Mean & $\mathrm{Sd}$ & Variance & Skewness & Kurtosis & Min & Max \\
\hline Male & 4.521084 & 4.378902 & 19.17478 & 0.7553161 & 2.093348 & 1 & 14 \\
\hline Female & 5.254355 & 3.866854 & 14.95256 & 0.1430305 & 1.733932 & 1 & 14 \\
\hline \multicolumn{8}{|c|}{ Source(s): Authors' computation 2020} \\
\hline
\end{tabular}

\begin{tabular}{lcc}
\hline Industry of occupation & Frequency & Percentage \\
\hline Agriculture & 113 & 39.37 \\
Manufacturing & 16 & 5.57 \\
Professional/scientific/technical & 4 & 1.39 \\
Buying and selling & 127 & 44.25 \\
Personal services & 11 & 3.83 \\
Education & 4 & 1.39 \\
Health & 2 & 0.70 \\
Public administration & 3 & 1.05 \\
Other specify & 7 & 2.44 \\
Source(s): Authors' computation 2020 & & \\
\hline
\end{tabular}

Source(s): Authors' computation 2020
Table 2.
Distribution of females according to the sector of employment 


\begin{tabular}{lcc}
\hline Industry of occupation & Frequency & Percentage \\
\hline Agriculture & 182 & 54.82 \\
Mining & 1 & 0.30 \\
Manufacturing & 8 & 2.41 \\
Professional/scientific/technical & 9 & 2.71 \\
Construction & 7 & 2.11 \\
Transportation & 15 & 4.52 \\
Buying and selling & 49 & 14.76 \\
Financial services & 3 & 0.90 \\
Personal services & 16 & 4.82 \\
Education & 11 & 3.31 \\
Health & 3 & 0.90 \\
Public administration & 18 & 5.42 \\
Other specify & 10 & 3.01
\end{tabular}

\section{Gender inequality in Nigeria}

Source(s): Authors' computation 2020

Table 3.

Distribution of males according to the sector employment

\begin{tabular}{|c|c|c|c|c|}
\hline & No wage & Has wage & All & \\
\hline \multicolumn{5}{|l|}{ Gender } \\
\hline Male & 48.48 & 65.67 & 49.12 & \\
\hline Female & 52.52 & 34.33 & 50.88 & \\
\hline \multicolumn{5}{|l|}{ Location } \\
\hline Urban & 28.05 & 52.82 & 28.96 & \\
\hline Rural & 71.95 & 47.18 & 71.04 & \\
\hline \multicolumn{5}{|l|}{ Region } \\
\hline North & 41.69 & 57.71 & 42.28 & \\
\hline South & 58.31 & 42.29 & 57.72 & \\
\hline \multicolumn{5}{|c|}{ Educational level } \\
\hline No education & 6.24 & 0.09 & 5.86 & \\
\hline Primary & 40.33 & 11.22 & 38.56 & \\
\hline Quranic & 8.24 & 1.30 & 7.81 & \\
\hline Secondary & 26.27 & 32.37 & 26.65 & \\
\hline Tertiary & 6.41 & 50.83 & 9.12 & \\
\hline Vocational & 12.51 & 4.17 & 12.00 & \\
\hline \multicolumn{5}{|c|}{ Sector of employment } \\
\hline Agriculture & 5.24 & 2.62 & 3.54 & \\
\hline Industry & 10.26 & 8.56 & 9.16 & \\
\hline Services & 81.00 & 86.92 & 84.83 & \\
\hline Others & 3.49 & 1.90 & 2.46 & \\
\hline \multicolumn{5}{|l|}{ Marital status } \\
\hline Married & 28.52 & 69.82 & 30.39 & \\
\hline Not married & 66.54 & 22.80 & 64.56 & Characteristics of wage \\
\hline Widowed & 4.94 & 7.38 & 5.05 & and nonwas \\
\hline \multicolumn{5}{|c|}{ Source(s): Authors' computation 2020} \\
\hline
\end{tabular}

wage", and 52.52 of females have "no wage", with females having a higher percentage. Furthermore, in the "has wage" category, the males dominate with $65.67 \%$, while $34.33 \%$ of females receive earnings in the formal sector; this further affirms the earlier finding that females engage in semiskilled works that offer little or no wage; hence, the disparity in the 
JBSED 1,2

income gap of about $31.34 \%$ exists along gender. This points to the existence of an imbalance in the wage employment in Nigeria.

The table also shows that in terms of employment according to location, the urban centers provide more wage employment ("has wage") than the rural area. In contrast, in the rural $(71.95 \%)$ area, "no wage" is higher than that of the urban area $(28.05 \%)$. This clearly shows that a larger percentage of rural dwellers engage in unpaid employment. More so, the "has wage" category in urban areas at $52.82 \%$ against $47.18 \%$ in the rural area confirmed the $a$ priori expectation of the distribution of paid employment to be skewed in urban dwellers' direction.

Educational level is a major factor in income distribution. The level of education determines the level of income that an individual receives and either it will be in the wageearning category or not. The result shows that the larger percentage of the "no wage" category have primary school education $(40.33 \%)$ followed by those with secondary school certificate $(26.27 \%$ ). About $50.83 \%$ of those with paid employment have tertiary education, followed by individuals with secondary education (32.37\%). This also confirms the prior expectation that more years of schooling should be income rewarding. Hence, inequality as the result of education is due to years of schooling. As more of the general populace attend school, the lesser the inequality as a result of education.

The service sector offers more paid employment than the other sectors with $86.92 \%$, followed by the industrial sector with $8.29 \%$.

Furthermore, the study found that those who are not married engaged more in informal employment (no wage), representing about $66 \%$; on the other hand, the married are found more in wage-earning employment. Therefore, an inequality gap in income exists between the married and the singles.

Wage equations were estimated using OLS regression to identify the determinants of earning inequality in Nigeria (Table 5). The overall goodness of fit for the model is $25.10 \%$, with education playing a vital role in the contribution to earnings; agriculture shows a negative relationship. Also, marital status at all levels proves to be negative, primary and the north also experience a negative outcome.

Other variables in the model prove to be positively related with the log of monthly earnings, that is, gender, region, and secondary, tertiary, and vocational education; therefore, we accept the hypothesis stated. Table 6 also presents the average group earning of the categories. Inequality in wage between males and females was evident. The average earning of males was almost twice that of females, showing a high disparity in the level of income received by both genders.

Considering earnings by location, urban areas receive more earnings on average than the rural areas, representing that the urban areas are better off. In terms of region, the inequality measured by average earning favors the southern region over the northern region. Furthermore, evidence suggests that those who have higher education earn more than others and that the higher the level of education, the higher the earning. Earnings based on the sector of employment favors those in the agriculture sector. They also form a large percentage of the respondent, while those who are in the service sector also outweigh the industrial sector in terms of earnings.

Figure 1 shows that the female wage sprout over that of male to the left. The majority of the low wage earners are females; the male gender with higher incomes than the female tends to the right.

Figure 2 describes the relationship between the rural and urban regions. The graph shows that rural areas have a higher number of workers receiving lower income than the urban region with a higher number of workers in high-income jobs. In another vain, South and North regions have a close and almost similar wage distribution. However, the north experienced a higher number of people with a lower wage. The south has people with higher wage as it 


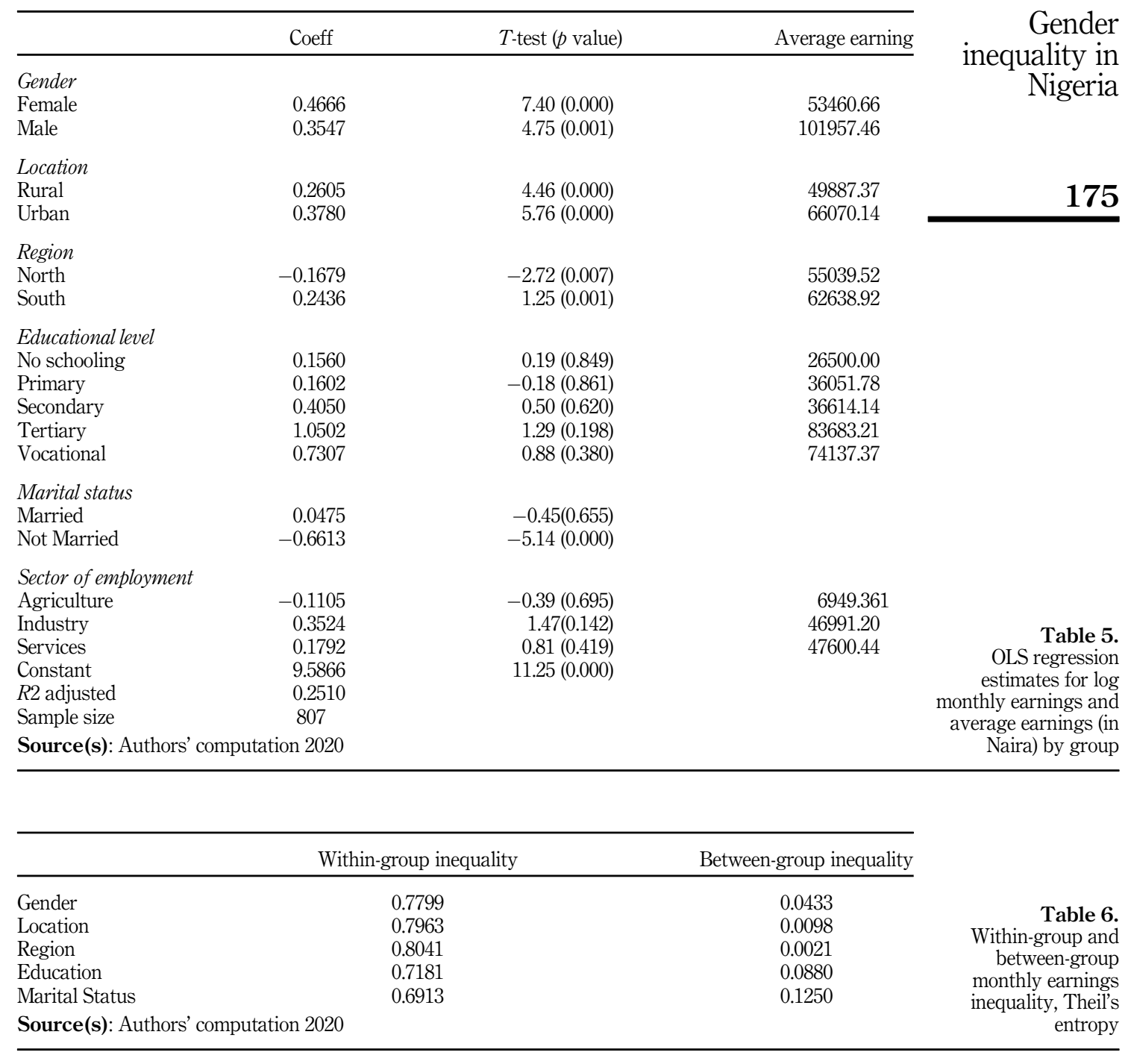

tends to the right. The kernel density graph further established findings in the regression analysis.

One of the objectives of this paper was to examine inequality between and within the group. We proceed to examine inequality within and between gender, location, region, education and marital status with Theil's entropy index, which allows for this operation. The result is presented in Table 6 .

Total earnings inequality was decomposed using Theil's entropy (Table 6). Theil's entropy index assumes the maximum value of 1 as absolute inequality and 0 as equity. Within-group inequality explains inequality in relation to such group (internally), while the between-group measures inequality in relation to other groups (external). Within-group 


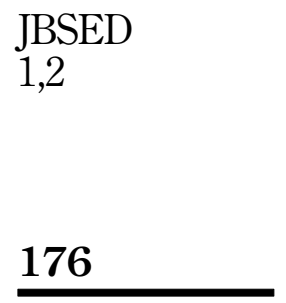

Figure 1.

Shows the distribution of wage by gender

Figure 2.

Shows the distribution of wage by location

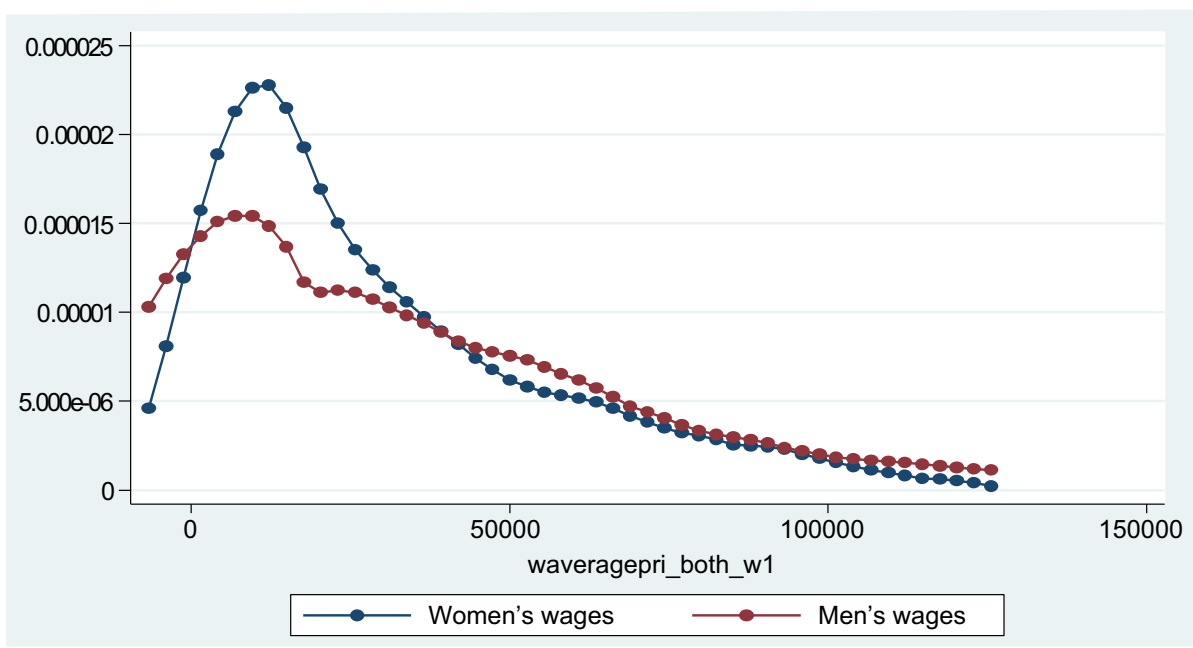

Source(s): Authors computation 2020

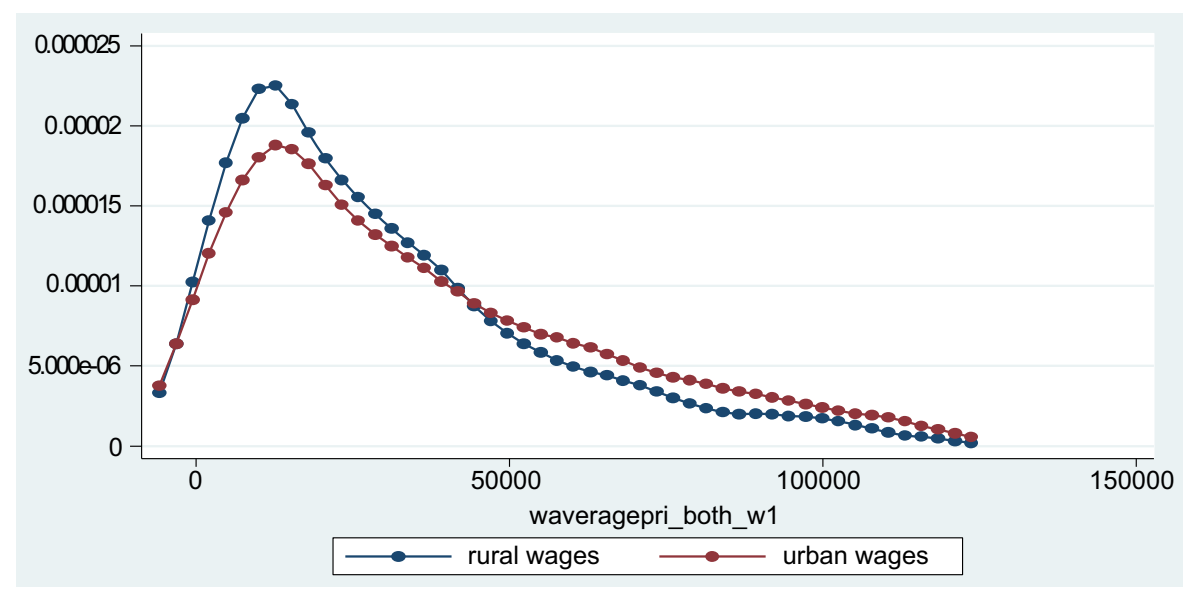

Source(s): Authors computation 2020

inequality is dominant in Nigeria. Along gender measured by male and female, the within inequality (0.7799) is of high value and close to the threshold of absolute inequality. Inequality also prevails within the rural and the urban areas (0.7963). Region experiences the highest level of within inequality in the study (0.8041). This shows a high gap in income considering the north and south of Nigeria and geographical area contributes more to inequality in earnings in Nigeria. Marital status also witnesses a high level of within inequality.

Considering the between-group inequality, between-group inequality is relatively low when compared with the within-group inequality. This shows that the variables are independent of other factors that can affect them externally. Marital status has the highest level of inequality (0.125), followed by education (0.088) and gender $(0.043)$. This shows that 
females are highly deprived when married, and when it comes to education, they are relegated to the back.

\section{Conclusion and recommendation}

This paper focuses on inequality in earning in Nigeria; more specifically, the paper explores inequality in earning and gender, region (rural and urban areas), location (north and south), level of educational attainment and marital status. We measure the within-group, and between-group inequality; regression analysis, a graphical analysis was also carried out. The paper explored wage and nonwage employment characteristics, average earnings (in Naira) by group, and used the kernel density graph to explain relationships.

Findings from the paper empirically confirm that the presence of inequality in earnings prevails in Nigeria. It is observed that within-group inequality has the larger share of the inequality, while the between-group inequality only accounts for minimal contribution to inequality in earnings in Nigeria. Moreover, there are more male $(65.67 \%)$ wage earners than females $(34.33 \%)$. Females have a higher return on education than males. The service sector contributed $86.92 \%$ to the "has-wage" category, while $69.82 \%$ of the female wage earners are married. Average earnings for both urban and rural workers stood at 66,070.14 and 49,887.37 Naira, respectively. This shows the wide gap that exists in earnings in both locations. Based on regional comparison, residents in the southern part of the country earned more (N62,638.92) than their northern counterparts (N55,039.52). This finding is consistent with the earlier studies of Checchi and van De Werfhorst (2018).

Generally, there is a high level of inequality in Nigeria. Specifically, within-group inequality is found to be more in the categories of regions (0.80409) and location (0.79634) than in the category of gender (0.77988). This shows that the location where a worker resides could worsen the degree of inequality experienced. Furthermore, inequality was explained by the sector of employment, location and religion. The model had a good fit. To this end, this study has contributed to the overcrowding theory of Amasa Walker by validating the concepts and showing that the female labor force in Nigeria is denied wage-earning opportunities. It is evident from the study that the female gender still has no access and control over resources, and cannot even influence their power as women in the country's political arena. They are relegated to the agriculture and small trade sector of the economy. These sectors currently witness many women; they are largely underproductive and receive poor earnings.

We recommend that gender inequality in earnings can be solved by policies aimed at benefiting the female categories. Such policies should encourage their participation more in wage-paying jobs than the traditional house jobs that many have been relegated to do. Furthermore, the education of a girl child is important in bridging the inequality gap in earnings. It has proven that females have higher returns to education than males as revealed by the kernel density graph.

The government is encouraged to explore affirmative actions, provide facilities and incentives that will encourage female students to further their education. This is in line with our findings which shows that the tertiary level of education provides higher returns than lower levels of education for females. Inequality across region seems to affect the economy greatly as a result shows that some region that is the south is better than the north, therefore, steps to develop the region should be of top priority for the government and the concerned stakeholders such as the multinational companies and private companies in terms of providing wage-paying jobs.

Human capital development must be given adequate attention at all levels of government. Opinion leaders like religious and traditional rulers should be courted to push even more for the girl child. Infrastructure development and opportunities leveraging on the local

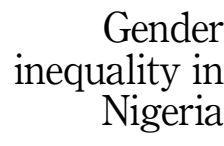


JBSED

1,2

endowments and economically viable activities should be aggressively initiated in less developed regions.

In as much as we have been able to identify various shades of gender inequality in the Nigerian economy, more emphasis has been on earning. We further confirm that inequality in educational achievement is a factor that contributes to the gap in earning. Therefore, we propose that further study can examine the root cause of educational inequality along gender, regions and at different level of education in Nigeria so as to make the female gender have equal access to resources available in the country and further strengthen their participation in the political arena also.

\section{References}

Abendroth, A.K., Melzer, S., Kalev, A. and Tomaskovic-Devey, D. (2017), "Women at work: women's access to power and the gender earnings gap”, ILR Review, Vol. 70 No. 1, pp. 190-222.

Adegbite, O.O. and Machethe, C.L. (2020), "Bridging the financial inclusion gender gap in smallholder agriculture in Nigeria: an untapped potential for sustainable development", World Development, Vol. 127, 104755.

Agbasiere, J.T. (2015), Women in Igbo Life and Thought, Routledge, New York.

Akinbi, J.O. and Akinbi, Y.A. (2015), "Gender disparity in enrolment into basic formal education in Nigeria: implications for national development", African Research Review, Vol. 9 No. 3, pp. 11-23.

Anyalebechi, L. (2016), "The issue of gender inequality in Nigeria”, Journal of Policy and Development Studies, Vol. 289 No. 3519, pp. 1-9.

Archibong, B. (2018), "Historical origins of persistent inequality in Nigeria", Oxford Development Studies, Vol. 46 No. 3, pp. 325-347.

Aspromourgos, T. (1986), "On the origins of the term neoclassical", Cambridge Journal of Economics, Vol. 10 No. 3, pp. 265-270.

Azuakor, P.O. (2017), "The women's place in family inheritance in Igboland", Nnadiebube Journal of Social Sciences, Vol. 1 No. 2.

Busemeyer, M.R. (2015), Skills and Inequality: Partisan Politics and the Political Economy of Education Reforms in Western Welfare States, Cambridge University Press, Cambridge.

CEIC (2019), "Nigeria government debt percentage of GDP 1981-2019", available at: https://www. ceicdata.com/en/indicator/nigeria/government-debt-of-nominal-gdp (accessed 25 April 2020).

Checchi, D. and van De Werfhorst, H.G. (2018), "Policies, skills and earnings: how educational inequality affects earnings inequality", Socio-Economic Review, Vol. 16 No. 1, pp. 137-160.

Clark, R. (2011), "World health inequality: convergence, divergence, and development", Social Science and Medicine, Vol. 72 No. 4, pp. 617-624, doi: 10.1016/j.socscimed.2010.12.008.

Connell, A., Holder, A. and Kearney, H. (2020), "Equal Measures 2030: a new approach for advocacy and influencing beyond Beijing+ 25", Gender and Development, Vol. 28 No. 2, pp. 405-423.

Cowell, F. (2006), "Theil, inequality indices and decomposition”, Dynamics of Inequality and Poverty, Vol. 13 No. 13012, pp. 341-356.

Dorius, S.F. and Firebaugh, G. (2010), "Trends in global gender inequality”, Social Forces, Vol. 88 No. 5, pp. 1941-1968.

Ene-Obong, H.N., Onuoha, N.O. and Eme, P.E. (2017), "Gender roles, family relationships, and household food and nutrition security in Ohafia matrilineal society in Nigeria", Maternal and Child Nutrition, Vol. 13, p. e12506. 
Essien, S.N., Agboegbulem, N., Mba, M.K. and Onumonu, O.G. (2016), "An empirical analysis of the macroeconomic impact of public debt in Nigeria", CBN Journal of applied statistics, Vol. 7 No. 1, pp. $125-145$.

Falk, A. and Hermle, J. (2018), "Relationship of gender differences in preferences to economic development and gender equality", Science, Vol. 362 No. 6412, p. eaas9899.

Fantom, N. and Serajuddin, U. (2016), "The World Bank's classification of countries by income”, Policy Research working paper; no. WPS 7528, World Bank, Geneva.

Fatukasi, A.A. and Ayeomoni, O.I. (2015), "Effect of income inequality on health indicators in Nigeria (1980-2014)", International Journal of Academic Research in Business and Social Sciences, Vol. 5 No. 8, pp. 274-285, doi: 10.6007/IJARBSS/v5-i8/1784.

Ferguson, C.E. (1969), The Neoclassical Theory of Production and Distribution, Cambridge, New York, pp. 1-10, ISBN: 9780521076296, ch. 1.

Fidelis, O.O., Alaba, O.A., Alaba, O.B., Alayande, B.A. and Okojie, C.E. (2006), "Labour force participation, earnings and inequality in Nigeria", SARPN Acknowledges the African Economic Research Consortium (AERC), pp. 10-12.

Hegewisch, A. and Williams-Baron, E. (2018), “The gender wage gap: 2017; earnings differences by gender, race, and ethnicity", Institute for Women's Policy Research. Fact Sheet: Pay Equity and Discrimination. ID C, 473.

Iceland, J. (2004), “The multigroup entropy index (also known as Theil's $\mathrm{H}$ or the information theory index)", US Census Bureau, p. 2006, July 31.

ILO (International Labour Organization) (2011), “O.E.C.D definitions”, Center for Global Development, pp. 1-5.

IMF (2020), "World economic outlook database", available at: Imf.org, (accessed April 17 2020).

Isiksal, A.Z. and Chimezie, O.J. (2016), "Impact of industrialization in Nigeria", European Scientific Journal, Vol. 12 No. 10, pp. 328-339.

Kaplan, A. and Herbst, A. (2015), "Stratified patterns of divorce: earnings, education, and gender", Demographic Research, Vol. 32, pp. 949-982.

Kilmer, J.T. and Rodríguez, R.L. (2017), "Ordinary least squares regression is indicated for studies of allometry”, Journal of Evolutionary Biology, Vol. 30 No. 1, pp. 4-12.

Klasen, S. (2002), "Low schooling for girls, slower growth for all? Cross-country evidence on the effect of gender inequality in education on economic development", The World Bank Economic Review, Vol. 16 No. 3, pp. 345-373.

Klasen, S. (2008), "The impact of gender inequality in education and employment on economic growth in developing countries: updates and extensions", EUDN/WP 2008-10, pp. 1-40.

Klasen, S. and Santos-Silva, M. (2018), "Gender inequality as a barrier to economic growth: a review of the theoretical literature", Discussion Papers, No. 252, Georg-August-Universitä Göttingen, Courant Research Centre - Poverty, Equity and Growth (CRC-PEG), Göttingen.

Kleven, H. and Landais, C. (2017), "Gender inequality and economic development: fertility, education and norms", Economica, Vol. 84 No. 334, pp. 180-209.

Lawal, A.I., Somoye, R.O., Babajide, A.A. and Nwanji, T.I. (2018), "The effect of fiscal and monetary policies interaction on stock market performance: evidence from Nigeria", Future Business Journal, Vol. 4 No. 1, pp. 16-33.

Mandel, H. (2016), "The role of occupational attributes in gender earnings inequality, 1970 -2010", Social Science Research, Vol. 55, pp. 122-138.

Massey, D.S. and Denton, N.A. (1988), “The dimensions of residential segregation”, Social Forces, Vol. 67 No. 2, pp. 281-315. 
JBSED

1,2

Matthew, O., Adeniji, A., Osabohien, R., Olawande, T. and Atolagbe, T. (2020), "Gender inequality, maternal mortality and inclusive growth in Nigeria”, Social Indicators Research, Vol. 147 No. 3, pp. 763-780.

Mayoux, L. (1995), "Beyond naivety: women, gender inequality and participatory development", Development and Change, Vol. 26 No. 2, pp. 235-258.

Ndubuisi, P. (2017), "Analysis of the impact of external debt on economic growth in an Emerging Economy: evidence from Nigeria”, African Research Review, Vol. 11 No. 4, pp. 156-173.

Olanrewaju, J.A., Kona, H.U. and Dickson, T. (2015), "The dilemma of male child preference vis-à-vis the role of women in the Yoruba Traditional Religion and Society", Journal of Culture, Society and Development, Vol. 12, pp. 87-93.

Onafowora, O. and Owoye, O. (2019), "Impact of external debt shocks on economic growth in Nigeria: a SVAR analysis", Economic Change and Restructuring, Vol. 52 No. 2, pp. 157-179.

Osunde, O. (2015), "Labor market, demographic patterns and income inequality in Nigeria”, Journal of Sociology and Social Anthropology, Vol. 6 No. 3, pp. 341-354.

Ovadia, J.S. and Wolf, C. (2018), "Studying the developmental state: theory and method in research on industrial policy and state-led development in Africa", Third World Quarterly, Vol. 39 No. 6, pp. 1056-1076.

Para-Mallam, F.J. (2017), "Gender equality in Nigeria", Gender Equality in a Global Perspective, ROUTLEDGE in association with GSE Research, Vol. 23 No. 53, pp. 23-53.

Pathak, I. (2017), "Gender justice and law: a gender-specific study of landownership in uttarakhand", Understanding Women's Land Rights: Gender Discrimination in Ownership, Vol. 13, p. 376.

Rewhorn, S. (2020), "Systems of equity: achieving health and wellbeing for rural communities", in Leal Filho, W., Wall, T., Azul, A.M., Brandli, L. and Özuyar, P.G. (Eds), Good Health and Well-Being, Encyclopedia of the UN Sustainable Development Goals, Springer, Cham, doi: 10.1007/978-3319-95681-7_86.

Theil, H. (1972), Statistical Decomposition Analysis, North-Holland Publishing Company, Amsterdam.

Uduji, J.I. and Okolo-Obasi, E.N. (2018), "Young rural women participation in the e-wallet programme and usage intensity of modern agricultural inputs in Nigeria", AGDI Working Paper, No. WP/ 18/062, African Governance and Development Institute (AGDI), Yaoundé.

UNDP (2013), Humanity Divided: Confronting Inequality in Developing Countries, available at: https:// www.refworld.org/docid/52fcc3fe4.html.

UNDP (2015), “Africa human development report 2016”, Advancing Gender Equality and Women's Empowerment in Africa, Regional Bureau for Africa 1 UN Plaza, New York, NY.

UNDP (2019), "Human development index (HDI)", available at: hdr.undp.org.

World Bank (2011), "Poverty headcount ratio", available at: https://data.worldbank.org/indicator/SI. POV.NAHC? locations $=$ NG.

World Health Organization (2020), available at: https://www.who.int/health-topics/gender.

Worsdale, R. and Wright, J. (2020), "My objectivity is better than yours: contextualising debates about gender inequality", Synthese, pp. 1-25, doi: 10.1007/s11229-020-02835-5.

Young, J. and Wessnitzer, J. (2016), "Descriptive statistics, graphs, and visualisation”, Modern Statistical Methods for HCI, Springer, Cham, pp. 37-56.

\section{Further reading}

IFAD (2013), Policy Brief: Improving Young Rural Women's and Men's Livelihoods, IFAD, Rome.

Kleven, H., Landais, C. and Søgaard, J.E. (2019), "Children and gender inequality: evidence from Denmark", American Economic Journal: Applied Economics, Vol. 11 No. 4, pp. 181-209. 
Oliver, A. and Mossialos, E. (2004), "Equity of access to health care: outlining the foundations for action", Journal of Epidemiology and Community Health, Vol. 58, pp. 655-658.

The Multigroup Entropy Index (2004), (Also Known as Theil's H or the Information Theory Index), December, pp. 1-10.

Walker, A. (1872), The Science of Wealth: A Manual of Political Economy, Lippincott, Philadelphia.

\section{Corresponding author}

Oluyemi Theophilus Adeosun can be contacted at: oluyemiadeosun@gmail.com 